Article

\title{
Properties of Particleboard from Oil Palm Biomasses Bonded with Citric Acid and Tapioca Starch
}

\author{
Radiah Zakaria ${ }^{1}$, Paiman Bawon ${ }^{1, *}$, Seng Hua Lee ${ }^{2, *}$, , Sabiha Salim ${ }^{1}$, Wei Chen Lum ${ }^{3, *}$, \\ Syeed Saifulazry Osman Al-Edrus ${ }^{1}$ (I) and Zawawi Ibrahim ${ }^{4}$
}

1 Faculty of Forestry and Environment, Universiti Putra Malaysia, Serdang 43400, Selangor, Malaysia; radiahzakaria@gmail.com (R.Z.); sabiha@upm.edu.my (S.S.); saifulazry@upm.edu.my (S.S.O.A.-E.)

2 Institute of Tropical Forestry and Forest Product (INTROP), Universiti Putra Malaysia, Serdang 43400, Selangor, Malaysia

3 Institute for Infrastructure Engineering and Sustainable Management (IIESM), Universiti Teknologi MARA, Shah Alam 40450, Selangor, Malaysia

4 Malaysian Palm Oil Board (MPOB), No. 6, Persiaran Institusi, Bandar Baru Bangi, Kajang 43000, Selangor, Malaysia; zawawi@mpob.gov.my

* Correspondence: paiman@upm.edu.my (P.B.); lee_seng@upm.edu.my (S.H.L.); lumweichen@outlook.com (W.C.L.)

Citation: Zakaria, R.; Bawon, P.; Lee, S.H.; Salim, S.; Lum, W.C.; Al-Edrus, S.S.O.; Ibrahim, Z. Properties of Particleboard from Oil Palm Biomasses Bonded with Citric Acid and Tapioca Starch. Polymers 2021, 13, 3494. https://doi.org/10.3390/ lpolym13203494

Academic Editors:

Antonio M. Borrero-López,

Concepción Valencia-Barragán,

Esperanza Cortés Triviño,

Adrián Tenorio-Alfonso and

Clara Delgado-Sánchez

Received: 20 August 2021

Accepted: 28 September 2021

Published: 12 October 2021

Publisher's Note: MDPI stays neutral with regard to jurisdictional claims in published maps and institutional affiliations.

Copyright: (c) 2021 by the authors. Licensee MDPI, Basel, Switzerland. This article is an open access article distributed under the terms and conditions of the Creative Commons Attribution (CC BY) license (https:// creativecommons.org/licenses/by/ $4.0 /)$.
Abstract: The study investigated the effects of the addition of starch on the properties of oil palm biomass particleboard bonded with citric acid. Three kinds of oil palm biomasses were used in this study for the fabrication of particleboard, namely, oil palm frond (OPF), oil palm trunk (OPT), and empty fruit bunch (EFB) particles. Citric acid and tapioca starch at the mixing ratios of 100:0, 87.5:12.5, and 75:25 were prepared at a 60\% solid content. A 30\% resin content based on the oven-dried weight of the oil palm biomass particles was used. The sprayed particles were pre-dried at $80{ }^{\circ} \mathrm{C}$ for $12 \mathrm{~h}$ before being hot-pressed at $180^{\circ} \mathrm{C}$ and $4 \mathrm{MPa}$ pressure for $10 \mathrm{~min}$. The physical and mechanical properties of the particleboard were evaluated. The mixtures of citric acid and tapioca starch were characterized by thermogravimetric analysis (TGA). Thermal stability of citric acid was reduced after the addition of tapioca starch. The addition of $12.5 \%$ tapioca starch improved the bending strength of the particleboard but increased the thickness swelling slightly. All UF-bonded particleboard exhibited significantly inferior performance than that of citric-acid-bonded particleboard. Citric-acid-bonded particleboard maintained its original shape after being subjected to a cyclic-aging treatment, while the UF-bonded particleboard disintegrated half way through the treatment. The performance of EFB particleboard was significantly inferior to its OPT and OPF counterparts.

Keywords: citric acid; oil palm trunk; oil palm frond; empty fruit bunch; cyclic aging treatment

\section{Introduction}

Malaysia is one of the main palm oil producers and exporters worldwide. As of December 2020, the total oil palm planted area in Malaysia amounted to 5.865 million hectares. Of the planted area, 53.3\% is in East Malaysia (Sabah and Sarawak), while the remaining 46.7\% is in Peninsular Malaysia [1,2]. According to Khalil et al. [3], the replanting activities and oil palm industry has generated at least 30 million tons of underutilized residues in the form of trunks, fronds, empty fruit bunches, and leaves every year. These oil palm biomasses could be categorized into two general types based on their generation sites. Oil palm trunks (OPT) and oil palm fronds (OPT) are readily available in the planting sites. The combination of OPT and OPF amounted to $75 \%$ of the total oil palm biomasses [4]. The remaining $25 \%$ are those generated at the mill sites after the extraction of fresh fruit bunches for palm oil, including empty fruit bunches (EFB), palm shell kernels, and palm oil mill effluent (POME). These oil palm biomass residues could be converted into value-added products to avoid wastage. Particleboard is one of the ideal options as any lignocellulosic materials could be used in particleboard production [5]. 
Citric acid is a natural chemical substance that could be found in various fruits and vegetables, especially in citrus fruits. Lemons and limes are among citrus fruits that contain a higher concentration of citric acid [6]. Thanks to its adhesivity and green nature, citric acid could be a good candidate as the main binding agent for wood and wood-based products. Umemura et al. [7] reported that the good adhesivity and bonding properties are a result of the ester linkages formed as the carboxyl groups of citric acid reacts with the hydroxyl groups of the wood constituent. In fact, citric acid has been used as a main binding agent for several types of wood composites such as particleboard, fiberboard, plywood, and laminated veneer lumber [8]. Citric-acid-bonded particleboard is among the most extensively studied wood composites. In recent years, due to the persistent environmental issues, application of non-formaldehyde-based or green binders from renewable resources has become an irresistible general trend. Citric acid could serve ideally to address this problem.

In the production of particleboard, many additives could be added to the citric acid in order to improve the performance of the resultant boards. For example, Umemura et al. [9] added sucrose to citric acid to improve the bonding performance of the particleboard. On the other hand, teak particleboard was fabricated using citric acid and sucrose, and improvement in dimensional stability was reported [10]. Apart from sucrose, starch could also be added to citric acid to enhance the performance of particleboard. Widyorini et al. [11] fabricated petung bamboo (Dendrocalamus sp.) particleboard bonded with different ratios of citric acid and starch. It was found that an addition of $12.5 \mathrm{wt} \%$ starch could improve the dimensional stability and bending strength of the particleboard. The authors attributed the improvement to the strong hydrogen bond interactions between citric acid and starch. The authors also reported that the amount of amylose in starch is a deciding factor to the dimensional stability of particleboard. Starch with higher amylose tends to result in particleboard with better dimensional stability as the linear chains of amylose are able to form strong linkages that are responsible for better water resistance.

A variety of wood and non-wood materials have been used in the production of citricacid-bonded particleboard such as bamboo [12], teak [10], sweet sorghum bagasse [13], Nipa fronds [14], alang-alang (Imperata cylindrica) [15], new giant reed (Arundo Donax L.) [16], sugarcane bagasse [17], and rubberwood [18]. However, to the best of the authors' knowledge, studies on the citric-acid-bonded particleboard made from oil palm biomasses such as oil palm trunk (OPT), oil palm frond (OPF), and empty fruit bunch (EFB) have yet to be reported. The effects of starch addition on the performance of citric acid as a binder for these oil palm biomasses is also unknown. Therefore, the objectives of this study were to investigate the performance of three oil palm biomasses bonded with citric and tapioca starch at different ratios.

\section{Materials and Methods}

\subsection{Preparation of Materials}

Three types of oil palm biomasses, namely, oil palm trunk (OPT), oil palm frond (OPF), and empty fruit bunch (EFB) were used in this study. Both OPT and OPF were collected from the felled oil palm trees in an oil palm field at Universiti Putra Malaysia. A portable wood chainsaw (STIHL M170, Waiblingen, Stuttgart, Germany) was used to reduce the size of the OPT and OPF before ground into particle sizes. On the other hand, fibers of EFB were supplied by a local company located at Dengkil, Selangor. The distribution of the particles' width and length are shown in Figure 1. Most of the OPT and OPF particles had a width ranging between 0.5 to $1.0 \mathrm{~mm}$, while the majority of the EFB particles had a width less than $0.1 \mathrm{~mm}$. In terms of length, the EFB particles used in this study were longer than that of OPT and OPF particles. All of the oil palm biomasses were dried in an oven at $60{ }^{\circ} \mathrm{C}$ for 7 days to achieve a $3 \%$ moisture content before particleboard fabrication. Citric acid in powder form was purchased from Evergreen Engineering \& Resources, Semenyih, Selangor, Malaysia. Tapioca starch was purchased from a grocery store, Serdang, Selangor, Malaysia. Citric acid and tapioca starch were dissolved into distilled water to achieve a 
$60 \%$ resin solid content. The citric acid and tapioca starch mixture ratios were set at 100:0, 87.5:12.5, and 75:25 (w/w).
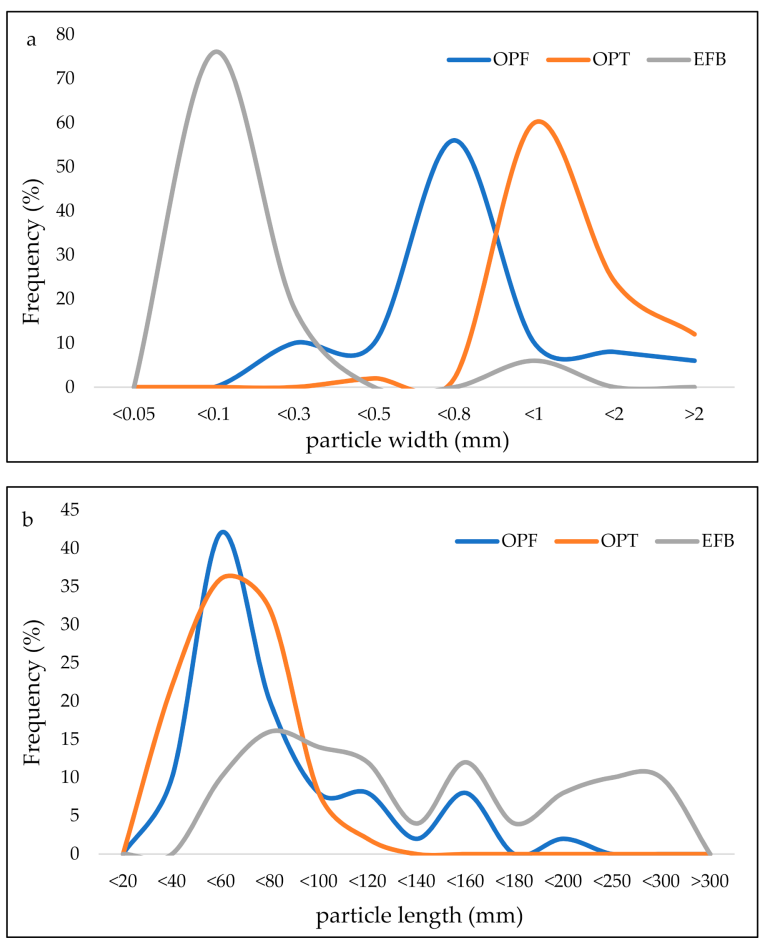

Figure 1. Distribution of width (a) and length (b) of oil palm frond (OPF), oil palm trunk (OPT), and empty fruit bunch (EFB) particles used in this study.

\subsection{Fabrication of Particleboard}

Single-layer particleboard was produced using citric acid and tapioca starch at different ratios (100:0, 87.5:12.5, and 75:25). Thirty percent resin loading based on the oven-dried weight of oil palm biomass particles were sprayed on the particles. The mixture was then mixed at room temperature for 5 min using a mixer machine (custom made). The mixing process was carried out carefully to ensure the mixture of citric acid and tapioca starch were spread evenly with the oil palm biomass particles. The mixed particle was then oven-dried in an oven at $80^{\circ} \mathrm{C}$ for $12 \mathrm{~h}$ prior to hot pressing. The oven-dried particles were then hand-formed into a mat using a $340 \mathrm{~mm} \times 340 \mathrm{~mm}$ wood mold. The mat was first pre-pressed to compact and then hot-pressed at $180^{\circ} \mathrm{C}$ for $10 \mathrm{~min}$ with a $4 \mathrm{MPa}$ pressure using a 100 Ton hydraulic laboratory hot press (Carver CMG 100H-15, Ontario, NY, USA). The pressing parameters were chosen according to the study by Lee et al. [8,19], where a pressing temperature of more than $180^{\circ} \mathrm{C}$ for $10 \mathrm{~min}$ was preferential for citric-acidbonded particleboard. A pair of 12-mm thick steel bar was used to control the thickness of the board during the hot-pressing process. Particleboards with final dimensions of $340 \mathrm{~mm} \times 340 \mathrm{~mm} \times 12 \mathrm{~mm}$ (length $\times$ width $\times$ thickness) with a target density of $650 \mathrm{~kg} / \mathrm{m}^{3}$ were produced. Three boards produced from a urea formaldehyde (UF) resin (65\% solid content) was used as a control. Ten $\mathrm{wt} \%$ resin loading was used to produce the control particleboard. One $\mathrm{wt} \%$ ammonium chloride was added to the UF resin as a hardener. After hot pressing, the boards were conditioned in a conditioning room setting at a temperature of $20 \pm 5{ }^{\circ} \mathrm{C}$ and a relative humidity of $65 \pm 5 \%$ until a constant mass was attained. The conditioned particleboards were then trimmed and cut according to the dimension requirements stated in JIS A 5908:2003 [20] for physical and mechanical properties' evaluation. Figure 2 shows the cutting pattern and sample sampling for the tests. For every particleboard, 2 replicates of samples for each test were obtained. Three replications of particleboard were produced for every citric acid/tapioca starch ratio and UF (control) resin in order to obtain 5 replicates for every physical and mechanical test. 


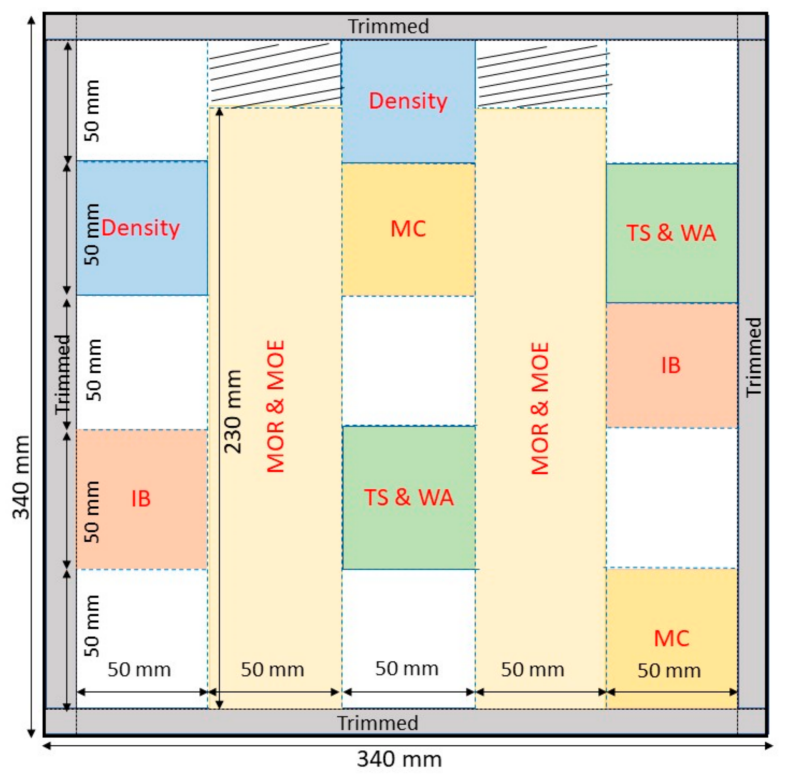

Figure 2. Cutting pattern and sample sampling for evaluation of density, moisture content (MC), thickness swelling (TS), water absorption (WA), internal bond (IB), modulus of rupture (MOR), and modulus of elasticity (MOE).

\subsection{Properties Evaluation}

2.3.1. Thermogravimetric Analysis (TGA) of Citric Acid/Tapioca Starch Binder

TGA of citric acid and topical starch mixture in powdered form was performed under a nitrogen atmosphere using the instrument TGA Q500 V20.13 Build 39 (TA Instruments, Pittsburgh, PA, USA) between 30 and $600{ }^{\circ} \mathrm{C}\left(10^{\circ} \mathrm{C} \mathrm{min}^{-1}\right)$ in the Laboratory of Biocomposite Technology, Institute of Tropical Forestry and Forest Products, Universiti Putra Malaysia, Serdang, Selangor.

\subsubsection{Chemical Composition and Bulk Density of Oil Palm Biomasses}

The determination of chemical content such as lignin, cellulose, hemicellulose, and extractives of the oil palm biomasses were conducted in accordance to the Technical Association of Pulp and Paper Industries (TAPPI) standard. The determination of lignin of the samples was conducted in accordance to TAPPI standard T222 os-74 [21], while the cellulose and hemicellulose was determined according to the procedure specified in TAPPI standard T203 os-74 [22] and Wise et al. [23], respectively. The bulk density of the particles of the oil palm biomasses were determined by using a cylinder method according to the study by Lee et al. [24]. A known weight of oil palm biomasses particles was put into a graduated cylinder half-filled with water. The amount of increment in water volume was recorded, and the bulk density was obtained by dividing the mass of the particles over volume increased.

\subsubsection{Mechanical Properties of Particleboard}

Test specimens were trimmed and prepared according to JIS A 5908:2003 [20] for properties' evaluation. Mechanical properties including the modulus of rupture (MOR), the modulus of elasticity (MOE), and the internal bond (IB) of the particleboard were evaluated in accordance with JIS A 5908:2003 [20]. The bending properties (MOR and MOE) were evaluated by using a three-point test on samples with dimensions of $230 \mathrm{~mm} \times 50 \mathrm{~mm} \times 12 \mathrm{~mm}$ (length $\times$ width $\times$ thickness). Meanwhile, the IB test was conducted on samples with dimensions $50 \mathrm{~mm} \times 50 \mathrm{~mm} \times 12 \mathrm{~mm}$ using a Universal Testing Machine (UTM, Instron-3366, Norwood, MA, USA). Five replicates were tested for each test. 


\subsubsection{Physical Properties of Particleboard}

The physical properties of the particleboard including water absorption (WA) and thickness swelling (TS) produced were evaluated in accordance with JIS A 5908:2003 [20]. The samples having a width and length of $50 \mathrm{~mm} \times 50 \mathrm{~mm}$ were immersed in water, and the weight and thickness of the immersed were weighed and measured at time intervals of 2 and $24 \mathrm{~h}$. The changes in thickness and weight before and after immersion were expressed as a percentage (\%). Cyclic aging treatment was performed according to Kusumah et al. [25]. The immersed samples (after $24 \mathrm{~h}$ ) were subjected to cyclic aging treatment in the following sequence:

$\begin{array}{ll}\text { i. } & \text { Drying at } 105^{\circ} \mathrm{C} \text { for } 10 \mathrm{~h} \\ \text { ii. } & \text { Immersion in water at } 70{ }^{\circ} \mathrm{C} \text { for } 10 \mathrm{~h} \\ \text { iii. } & \text { Drying at } 105^{\circ} \mathrm{C} \text { for } 10 \mathrm{~h} \\ \text { iv. } & \text { Immersion in boiling water for } 4 \mathrm{~h} \\ \text { v. } & \text { Drying at } 105^{\circ} \mathrm{C} \text { for } 10 \mathrm{~h}\end{array}$

The weight and thickness changes of the samples after every stage of the treatment were recorded. Five replicates were used for every test.

\subsubsection{Statistical Analysis}

The data collected were analyzed using Statistical Analysis System (SAS) software (SAS 9.4 solutions, Armonk, NY, United States). Analysis of variance (ANOVA) at a 95\% confidence level $(p \leq 0.05)$ was performed. Tukey's honest significant difference (HSD) test was used to further determine the significant level of average values for each treatment.

\section{Results and Discussion}

\subsection{Chemical Composition and Bulk Density}

The chemical composition and bulk density of the oil palm biomass particles used in this study are shown in Table 1. OPT had the highest lignin content of $26.47 \%$ compared with OPF (19.93\%) and EFB (21.17\%). Meanwhile, EFB had higher cellulose than that of OPT and OPF, while OPF had the highest content of hemicellulose (35.32\%). The extractive content for these three oil palm biomasses ranged from 1.54 to $4.80 \%$. The values reported are in agreement with the values reported in Abdul Khalil et al. [26]. They had a high cellulose content, making these oil palm biomasses very suitable in fabricating polymer composites [27].

Table 1. Chemical composition and bulk density of oil palm frond, oil palm trunk, and empty fruit bunch particles.

\begin{tabular}{cccc}
\hline Biomasses & Oil Palm Frond & Oil Palm Trunk & Empty Fruit Bunch \\
\hline Lignin $(\%)$ & $19.93 \pm 0.26$ & $26.47 \pm 0.46$ & $21.17 \pm 0.88$ \\
Holocellulose (\%) & $75.26 \pm 0.21$ & $71.99 \pm 0.48$ & $75.49 \pm 0.67$ \\
Cellulose $(\%)$ & $39.95 \pm 0.23$ & $42.47 \pm 0.19$ & $45.30 \pm 0.41$ \\
Hemicellulose $(\%)$ & $35.32 \pm 0.41$ & $29.52 \pm 0.41$ & $30.19 \pm 0.38$ \\
Extractive $(\%)$ & $4.80 \pm 0.07$ & $1.54 \pm 0.01$ & $3.34 \pm 0.12$ \\
Moisture content $(\%)$ & $7.41 \pm 0.01$ & $5.82 \pm 0.01$ & $6.70 \pm 0.01$ \\
Bulk density $\left(\mathrm{kg} / \mathrm{m}^{3}\right)$ & $560.80 \pm 15.73$ & $460.00 \pm 11.91$ & $670.20 \pm 22.40$ \\
\hline
\end{tabular}

Note: values after " \pm " are standard deviations.

As for bulk density, EFB had the highest bulk density of $670.20 \mathrm{~kg} / \mathrm{m}^{3}$, while the bulk densities for OPF and OPT were $560.80 \mathrm{~kg} / \mathrm{m}^{3}$ and $460.00 \mathrm{~kg} / \mathrm{m}^{3}$, respectively. The findings were comparable to the study by Abdul Khalil et al. [26] who reported that the bulk density of OPF, OPT, and EFB ranged between $600-1200 \mathrm{~kg} / \mathrm{m}^{3}, 500-1100 \mathrm{~kg} / \mathrm{m}^{3}$, and $700-1550 \mathrm{~kg} / \mathrm{m}^{3}$, respectively. However, the bulk density of oil palm biomasses reported in this study was higher than other agricultural plants such as sweet sorghum bagasse $\left(125 \mathrm{~kg} / \mathrm{m}^{3}\right)$ [25], kenaf core $\left(118 \mathrm{~kg} / \mathrm{m}^{3}\right)$ [28], and bamboo $\left(200 \mathrm{~kg} / \mathrm{m}^{3}\right)$ [29]. 


\subsection{Thermogravimetric Analysis (TGA)}

Figure 3 displays the thermogravimetric (TG) and derivative thermogravimetric (DTG) curves of binder mixed at different ratios of citric acid and tapioca starch. It can be seen from Figure 3 that pure citric acid started to degrade at around $150{ }^{\circ} \mathrm{C}$ and peaked at $224^{\circ} \mathrm{C}$ (Figure $3 \mathrm{~b}$ ). The observation is very close to the study by Silva et al. [30] who reported that the decomposition of citric acid occurred between a temperature range of 150 to $220^{\circ} \mathrm{C}$, and the DTG peak was at $210{ }^{\circ} \mathrm{C}$. The authors stated that $95 \%$ of the transformation of citric acid occurred within this temperature range. Nevertheless, the addition of starch reduced the initial degradation temperature of the mixture of citric acid and tapioca starch, as seen in Figure 3a. From the DTG curves shown in Figure 3b, one can see that the decomposition temperature was reduced to $210{ }^{\circ} \mathrm{C}$ when $12.5 \%$ and $25 \%$ tapioca starch was added. The observation indicates a lower thermal stability after the addition of starch [31]. A study by Ali et al. [32] revealed that the tapioca starch started to degrade at about $62{ }^{\circ} \mathrm{C}$ under a nitrogen atmosphere and continued to lose weight until $500^{\circ} \mathrm{C}$. Therefore, it might be one of the reasons that causes a reduction in the thermal stability of citric acid after the addition of starch.
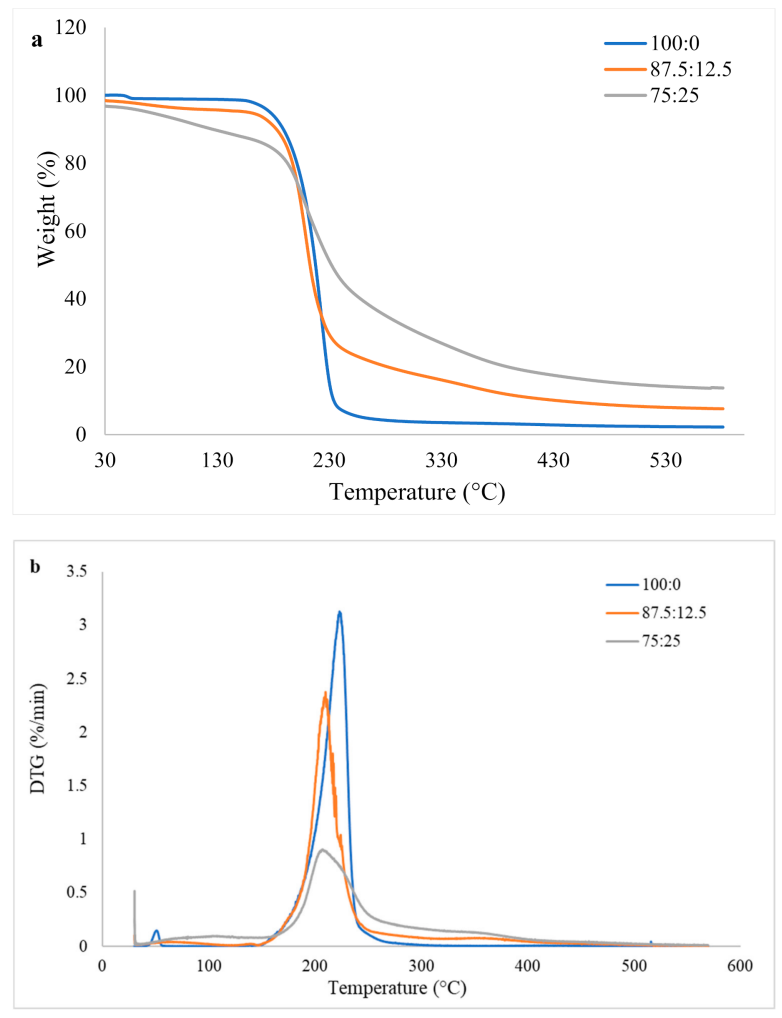

Figure 3. (a) Thermogravimetric (TG) and (b) derivative thermogravimetric (DTG) curves of binder mixed at different ratios of citric acid and tapioca starch.

The particleboard was hot-pressed at $180{ }^{\circ} \mathrm{C}$ in this study. At this temperature, pure citric acid experienced a weight loss of $5.9 \%$, while the mixture of citric acid and tapioca starch at 87.5:12.5 and 75:25 recorded weight losses of $9.0 \%$ and $15.8 \%$, respectively. The event implies a lower thermal stability of the mixture at a lower temperature. However, the mixture of citric acid and tapioca starch showed a higher resistance at a higher temperature, and their final residue was much higher than that of pure citric acid. Overall, the mixture of citric acid and tapioca starch at a ratio of 75:25 had the highest $\mathrm{T}_{80}$ (temperature for $80 \%$ weight loss), which was $388.3^{\circ} \mathrm{C}$, followed by $87.5: 12.5\left(281.4^{\circ} \mathrm{C}\right)$ and pure citric acid $\left(228.0^{\circ} \mathrm{C}\right)$. The final residues were $13.7 \%, 7.6 \%$, and $2.2 \%$, respectively. This might be due to the crosslinking of citric acid with starch through covalent bonding. As a higher degree of crosslinking with citric acid was achieved at higher starch loadings, the final residue 
also increased correspondingly [31]. Additionally, a higher residue could be a result of carbonized material and the ash of starch at a high temperature [32].

\subsection{Mechanical Properties of the Particleboard}

Table 2 demonstrates the mechanical properties of the particleboard produced in this study.

Table 2. Modulus of rupture (MOR), modulus of elasticity (MOE), and internal bonding (IB) of oil palm biomass particleboard bonded with different binders.

\begin{tabular}{|c|c|c|c|}
\hline Binder & $\operatorname{MOR}\left(\mathrm{N} / \mathrm{mm}^{2}\right)$ & $\operatorname{MOE}\left(\mathrm{N} / \mathrm{mm}^{2}\right)$ & IB $\left(\mathrm{N} / \mathrm{mm}^{2}\right)$ \\
\hline \multicolumn{4}{|c|}{ Oil palm frond } \\
\hline UF & $6.89 \pm 1.57^{\mathrm{d}, \mathrm{e}, \mathrm{f}}$ & $972.75 \pm 51.5^{\mathrm{e}}$ & $0.22 \pm 0.06^{\mathrm{d}, \mathrm{e}}$ \\
\hline 100CA:0 starch & $7.32 \pm 0.65^{\mathrm{c}, \mathrm{d}, \mathrm{e}}$ & $2299.49 \pm 250.38^{a}$ & $0.52 \pm 0.13^{\mathrm{a}}$ \\
\hline 87.5CA:12.5 starch & $9.28 \pm 0.63^{a, b}$ & $2471.98 \pm 143.67^{a}$ & $0.46 \pm 0.16^{\mathrm{ab}}$ \\
\hline 75 CA:25 starch & $10.24 \pm 0.53^{\mathrm{a}}$ & $2329.84 \pm 114.77^{\mathrm{a}}$ & $0.34 \pm 0.07^{\mathrm{bcd}}$ \\
\hline \multicolumn{4}{|c|}{ Oil palm trunk } \\
\hline UF & $6.44 \pm 0.45^{\mathrm{e}, \mathrm{f}, \mathrm{g}}$ & $578.12 \pm 60.48^{\mathrm{f}}$ & $0.25 \pm 0.02^{\mathrm{c}, \mathrm{d}, \mathrm{e}}$ \\
\hline 100CA:0 starch & $8.75 \pm 0.93^{a, b, c}$ & $1711.96 \pm 150.82^{b, c}$ & $0.44 \pm 0.02^{\mathrm{a}, \mathrm{b}}$ \\
\hline 87.5CA:12.5 starch & $8.24 \pm 0.75^{b, c, d}$ & $1873.79 \pm 62.28^{\mathrm{b}}$ & $0.40 \pm 0.03^{\mathrm{a}, \mathrm{b}}$ \\
\hline 75 CA:25 starch & $5.64 \pm 0.52^{\mathrm{f}, \mathrm{g}, \mathrm{h}}$ & $1500.05 \pm 65.13^{c, d}$ & $0.37 \pm 0.04^{b, c}$ \\
\hline \multicolumn{4}{|c|}{ Empty fruit bunch } \\
\hline UF & $4.49 \pm 0.33^{\mathrm{h}}$ & $854.04 \pm 63.81^{\mathrm{e}}$ & $0.12 \pm 0.01^{\mathrm{e}}$ \\
\hline 100CA:0 starch & $5.08 \pm 0.35 \mathrm{~g}, \mathrm{~h}$ & $1287.28 \pm 93.51^{\mathrm{d}}$ & $0.35 \pm 0.02^{b, c, d}$ \\
\hline 87.5CA:12.5 starch & $7.15 \pm 0.92^{\mathrm{c}, \mathrm{d}, \mathrm{e}, \mathrm{f}}$ & $1285.17 \pm 50.57^{\mathrm{d}}$ & $0.25 \pm 0.03^{\mathrm{c}, \mathrm{d}, \mathrm{e}}$ \\
\hline 75 CA:25 starch & $4.49 \pm 0.40^{h}$ & $772.51 \pm 64.69^{\mathrm{e}, \mathrm{f}}$ & $0.23 \pm 0.03^{c, d, e}$ \\
\hline
\end{tabular}

Note: values after " \pm " are standard deviations. Within the same column, mean values followed by the different letters ${ }^{\mathrm{a}-\mathrm{h}}$ were significantly different at $p \leq 0.05$.

UF-bonded OPF particleboard had an MOR and an MOE of $6.89 \mathrm{~N} / \mathrm{mm}^{2}$ and $972.75 \mathrm{~N} / \mathrm{mm}^{2}$, respectively. The MOR and MOE values increased as citric acid was used as a binder. It is interesting to note that the MOR of the OPF particleboard increased when higher starch was added to the citric acid. As for the MOE, the addition of $12.5 \%$ starch increased the MOE of the particleboard, but it started to decrease when $25 \%$ starch was added. On the other hand, OPT particleboard experienced the same trend as the OPF particleboard in terms of MOE. However, OPT particleboard showed a decreasing MOR trend as the starch addition increased. The MOR of OPT particleboard bonded with pure citric acid and 87.5CA:12.5 starch did not differ significantly. UF-bonded EFB particleboard had the lowest MOR value of $4.49 \mathrm{~N} / \mathrm{mm}^{2}$. However, EFB bonded with citric acid exhibited a higher MOR, particularly those bonded with 87.5CA:12.5 starch, which has a statistically higher MOR value than UF-bonded EFB particleboard. The MOE values of the citric-acid-bonded EFB particleboard also displayed a decreasing trend with increasing starch addition, but no significant different was detected between particleboard bonded with pure citric acid and 87.5CA:12.5 starch.

Citric-acid-bonded particleboard had a higher IB strength than that of UF-bonded particleboard. A very consistent trend was noticeable for the IB strength of citric-acidbonded particleboard as the IB values decreased with increasing starch addition. The maximum IB strength of pure citric-acid-bonded OPF, OPT, and EFB particleboard were $0.52 \mathrm{~N} / \mathrm{mm}^{2}, 0.44 \mathrm{~N} / \mathrm{mm}^{2}$, and $0.35 \mathrm{~N} / \mathrm{mm}^{2}$, respectively. However, with the addition of $12.5 \%$ starch, the IB strength decreased around $11.5 \%, 10 \%$, and $28.6 \%$ for OPF, OPT, and EFB particleboard, respectively. The IB strength of the particleboard experienced further decrement when $25 \%$ starch was added. All the particleboard bonded with citric acid achieved the minimum requirement of IB strength $\left(0.15 \mathrm{~N} / \mathrm{mm}^{2}\right)$ for type 8 particleboard as specified in JIS A 5908. Overall, with the exception of some outliers, the addition of $12.5 \%$ starch was beneficial to the bending strength of the particleboard. Further starch 
addition $(25 \%)$ could cause a disastrous effect to the mechanical strength of the fabricated particleboard.

Among the oil palm biomasses, particleboard made from OPF particles seemed to have the highest mechanical properties. This may be due to fact that OPF possesses thick fiber walls. Better bonding could be achieved as the lumen to cell wall ratio is high in OPF, which means OPF particles could be easily compressed closely together [33]. Both OPF and OPT particleboard have significantly better mechanical properties than that of EFB particleboard. One of the probable reasons leading to this observation might be the bulk density of the material itself. Boruszewski et al. [34] reported in their study that the particleboard manufactured from poplar with a lower bulk density achieved a more compacted structure. As a result, minimum voids existed in the boards and correspondingly lead to better mechanical strength. As shown in Table 1, EFB had the highest bulk density followed by OPF and OPT. Lower bulk density inevitably leads to a higher compaction ratio, and the mechanical properties of the boards also increased proportionately with an increasing compaction ratio [24]. In addition, the EFB was reported to have traces of oil on the fiber surfaces [35]. These oil traces caused the EFB to have lower wettability, which prevents the adhesive to be spread evenly on the surfaces of the particleboard. Consequently, it is very difficult for the EFB particleboard to achieve an effective bonding, and subsequently this leads to poor mechanical strength.

\subsection{Physical Properties}

Thickness swelling (TS) and water absorption (WA) of the particleboard fabricated in this study are listed in Table 3.

Table 3. Thickness swelling (TS) and water absorption (WA) of oil palm biomasses particleboard bonded with different binders after $2 \mathrm{~h}$ and $24 \mathrm{~h}$ immersion in water.

\begin{tabular}{|c|c|c|c|c|}
\hline Binder & $\mathrm{TS}_{2 \mathrm{~h}}(\%)$ & $\mathrm{TS}_{24 h}(\%)$ & $\mathrm{WA}_{2 \mathrm{~h}}(\%)$ & $\mathrm{WA}_{24 h}(\%)$ \\
\hline \multicolumn{5}{|c|}{ Oil palm frond } \\
\hline UF & $48.07 \pm 1.15^{\mathrm{d}}$ & $71.22 \pm 2.51^{\mathrm{e}}$ & $109.60 \pm 5.31^{h}$ & $140.01 \pm 2.85 \mathrm{~g}$ \\
\hline 100CA:0 starch & $6.73 \pm 0.63^{\mathrm{a}}$ & $12.85 \pm 1.00^{\mathrm{b}}$ & $49.46 \pm 2.40^{\mathrm{a}, \mathrm{b}}$ & $63.69 \pm 1.24^{\mathrm{a}, \mathrm{b}}$ \\
\hline 87.5CA:12.5 starch & $12.27 \pm 0.47^{\mathrm{b}}$ & $20.84 \pm 1.11^{\mathrm{c}}$ & $48.48 \pm 2.81^{\mathrm{a}, \mathrm{b}}$ & $62.60 \pm 2.87^{\mathrm{a}, \mathrm{b}}$ \\
\hline 75 CA:25 starch & $18.77 \pm 1.10^{\mathrm{c}}$ & $22.01 \pm 1.99^{\mathrm{c}}$ & $63.91 \pm 2.15^{\mathrm{d}}$ & $81.46 \pm 5.00^{\mathrm{d}}$ \\
\hline \multicolumn{5}{|c|}{ Oil palm trunk } \\
\hline UF & $44.19 \pm 3.08^{d}$ & $56.96 \pm 4.12^{\mathrm{d}}$ & $102.10 \pm 1.43 \mathrm{~g}$ & $128.01 \pm 4.03^{\mathrm{f}}$ \\
\hline 100CA:0 starch & $6.65 \pm 0.51^{\mathrm{a}}$ & $12.11 \pm 0.70^{b}$ & $46.97 \pm 1.91^{\mathrm{a}}$ & $57.25 \pm 1.15^{\mathrm{a}}$ \\
\hline 87.5CA:12.5 starch & $6.95 \pm 0.40^{\mathrm{a}}$ & $7.28 \pm 1.00^{\mathrm{a}}$ & $59.56 \pm 1.99^{c, d}$ & $73.01 \pm 1.55^{c}$ \\
\hline 75 CA:25 starch & $7.38 \pm 0.84^{\mathrm{a}}$ & $10.60 \pm 0.60^{\mathrm{a}, \mathrm{b}}$ & $55.00 \pm 0.84^{b, c}$ & $68.01 \pm 1.37^{b, c}$ \\
\hline \multicolumn{5}{|c|}{ Empty fruit bunch } \\
\hline UF & $90.86 \pm 5.11^{\mathrm{e}}$ & $144.02 \pm 4.55^{\mathrm{f}}$ & $176.64 \pm 6.58^{\mathrm{i}}$ & $185.55 \pm 4.71^{\mathrm{h}}$ \\
\hline 100CA:0 starch & $16.53 \pm 0.44^{\mathrm{c}}$ & $20.11 \pm 0.94^{c}$ & $93.29 \pm 3.17^{f}$ & $96.68 \pm 3.07^{\mathrm{e}}$ \\
\hline 87.5CA:12.5 starch & $20.04 \pm 1.34^{\mathrm{c}}$ & $24.63 \pm 0.78^{\mathrm{c}}$ & $81.79 \pm 2.89^{\mathrm{e}}$ & $87.24 \pm 3.63^{\mathrm{d}}$ \\
\hline 75 CA:25 starch & $19.96 \pm 1.07^{\mathrm{c}}$ & $23.01 \pm 1.27^{\mathrm{c}}$ & $87.26 \pm 2.45^{\mathrm{e}, \mathrm{f}}$ & $123.02 \pm 6.09^{f}$ \\
\hline
\end{tabular}

Note: values after " \pm " are standard deviations. Within the same column, mean values followed by the different letters, ${ }^{\text {a-h }}$ were significantly different at $p \leq 0.05$.

After $2 \mathrm{~h}$ immersion in water, the $\mathrm{TS}_{2 \mathrm{~h}}$ of the UF-bonded OPF, OPT, and EFB particleboards were $48.07 \%, 44.19 \%$, and $90.86 \%$, respectively. Meanwhile, $\mathrm{TS}_{24 \mathrm{~h}}$ values were $71.22 \%, 59.96 \%$, and $144.02 \%$, respectively. The observation is unsurprising as UF resin is known to be very instable at high relative humidity owing to its susceptible aminomethylene linkage [36]. However, the TS values of the particleboard dropped significantly when citric acid was used as a binder. The $\mathrm{TS}_{24 \mathrm{~h}}$ values of OPF, OPT, and EFB particleboards bonded with pure citric acid (100:0) were approximately one-sixth, one-fifth, and oneseventh of their respective UF counterparts. Both OPF and EFB particleboard bonded with pure citric acid had significantly lower $\mathrm{TS}_{24 \mathrm{~h}}$ values than the particleboard bonded with starch addition. The findings were in agreement with Widyorini et al. [11] who reported 
that the TS of bamboo particleboard increased along with increasing starch content. The authors attributed the increment of the TS to the solubility of starch in water. However, OPT particleboard bonded with 87.5CA:12.5 starch exhibited the lowest $\mathrm{TS}_{24 \mathrm{~h}}$ value of $7.28 \%$.

Similarly, particleboard bonded with citric acid had a significantly lower $\mathrm{WA}_{2 \mathrm{~h}}(46.97 \%$ to $93.29 \%)$ and $\mathrm{WA}_{24 \mathrm{~h}}(57.25 \%$ to $123.02 \%)$ than UF-bonded particleboard $(102.10 \%$ to $176.64 \%$ and $128.01 \%$ to $185.55 \%$, respectively). The findings indicate that the citric acid inhibited water absorption by the particleboard during the water-immersion test [25]. Among oil palm biomasses, EFB particleboard had higher WA values compared to that of the OPF and the OPT particleboards. The OPT particleboard had the lowest TS and WA values. Hashim et al. [37] stated that the particleboard made from non-trunk particles typically had higher TS or poor dimensional stability. As discussed previously, the surfaces of EFB are hydrophobic due to the existence of oil. This hydrophobic characteristic leads to poor resin spreading and prevents good particle-particle bonding [38]. Therefore, EFB particleboard has a very low dimensional stability.

The thickness and weight changes of oil palm biomass particleboards during cyclic aging treatment are shown in Figures 4-6.

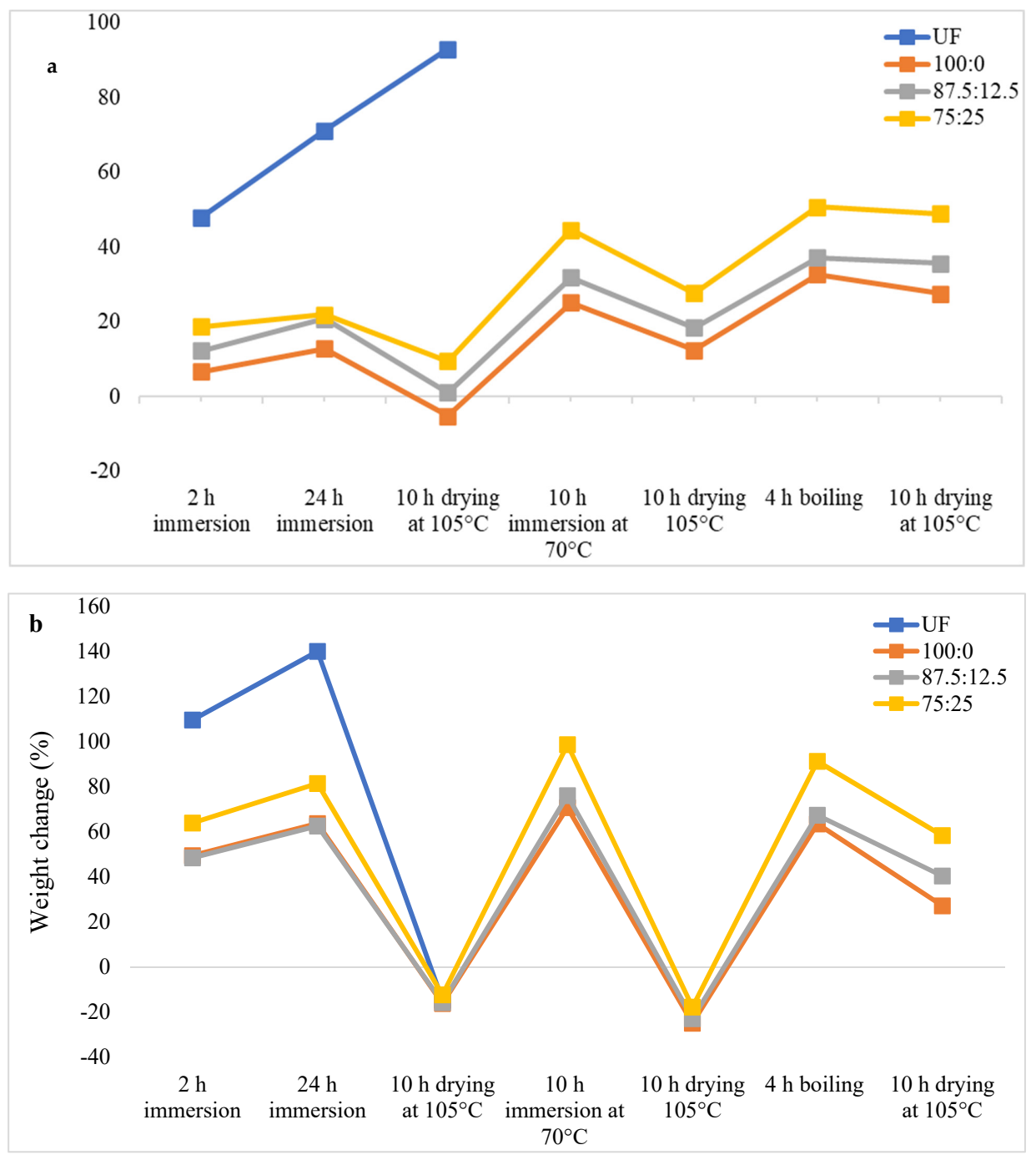

Figure 4. Thickness change (a) and weight change (b) of oil palm frond particleboard during cyclicaging treatment.

As shown in Figure 4, UF-bonded OPF particleboard was disintegrated after $24 \mathrm{~h}$ of immersion in water followed by drying at $105^{\circ} \mathrm{C}$ for $10 \mathrm{~h}$, which indicates very poor 
dimensional stability. In comparison, OPF particleboard bonded with citric acid displayed a much better dimensional stability compared to that of the UF-bonded particleboard. After boiling in hot water for $4 \mathrm{~h}$, the thickness changes of the particleboard bonded with pure citric acid (100:0) was 32.82\%. Meanwhile, particleboard bonded with 87.5CA:12.5 starch and 75CA:25 starch recorded thickness-change values of $37.18 \%$ and $50.77 \%$, respectively. The trend of weight change (Figure $4 \mathrm{~b}$ ) during and after the cyclic-aging treatment mirrored that of the thickness change as the particleboard bonded with pure citric acid exhibited the lowest weight-change value.
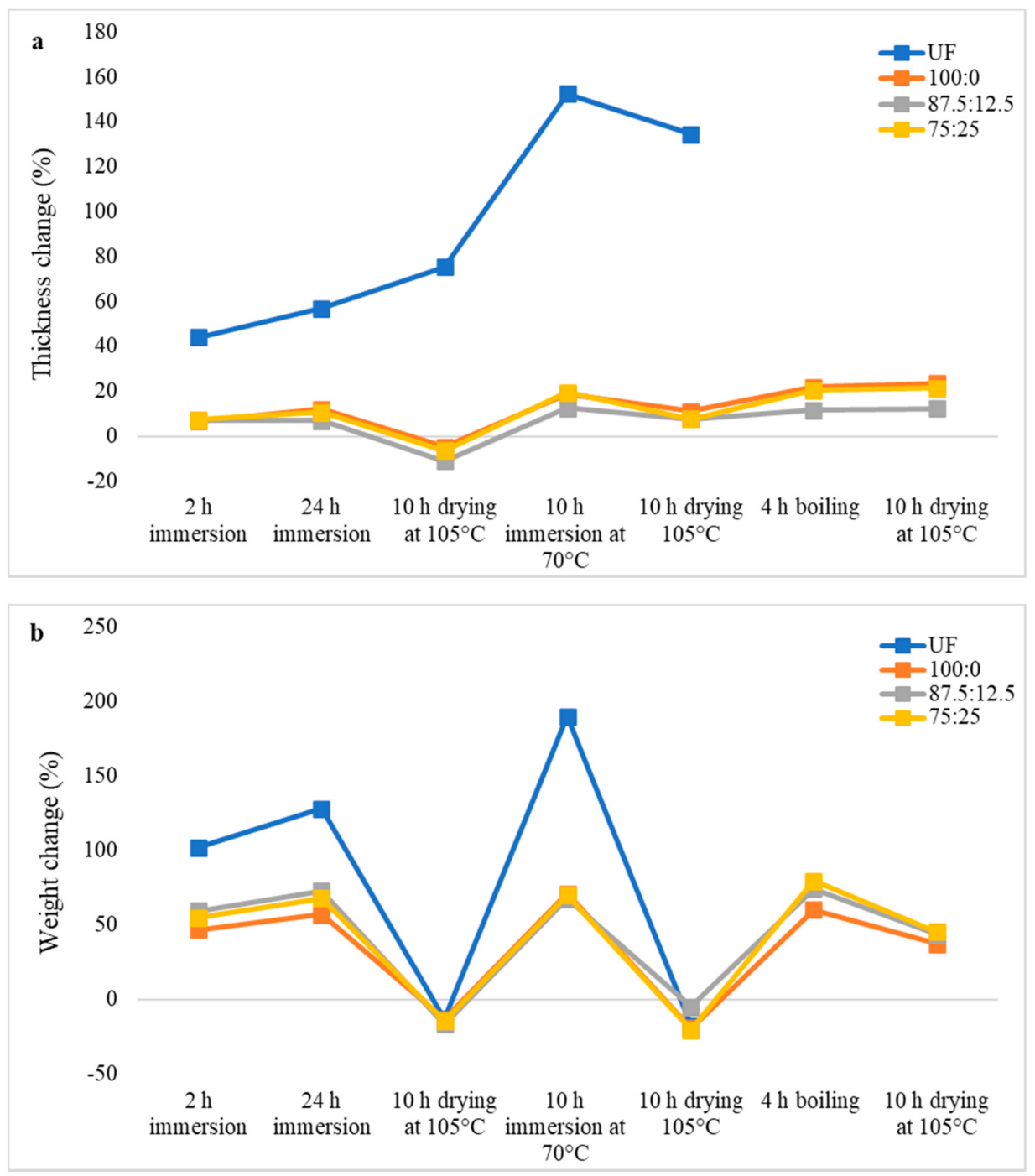

Figure 5. Thickness change (a) and weight change (b) of oil palm trunk particleboard during cyclicaging treatment.

UF-bonded OPT particleboards are the most dimensionally stable ones compared to that of the OPF and EFB particleboards. UF-bonded OPT particleboard experienced disintegration after the second drying stage at $105^{\circ} \mathrm{C}$, right after immersion in warm water at $70^{\circ} \mathrm{C}$ for $10 \mathrm{~h}$. Dissimilar to OPF particleboard, OPT particleboard bonded with 87.5CA:12.5 starch displayed the lowest thickness change of $11.69 \%$ after being boiled in hot water for $4 \mathrm{~h}$ (Figure 5a). The thickness change values of citric-acid-bonded OPT particleboard was more than two-fold lower than its OPF counterparts. Nevertheless, OPT particleboard bonded with pure citric acid exhibited the lowest weight change after $4 \mathrm{~h}$ of boiling in hot water (Figure $5 b$ ). 

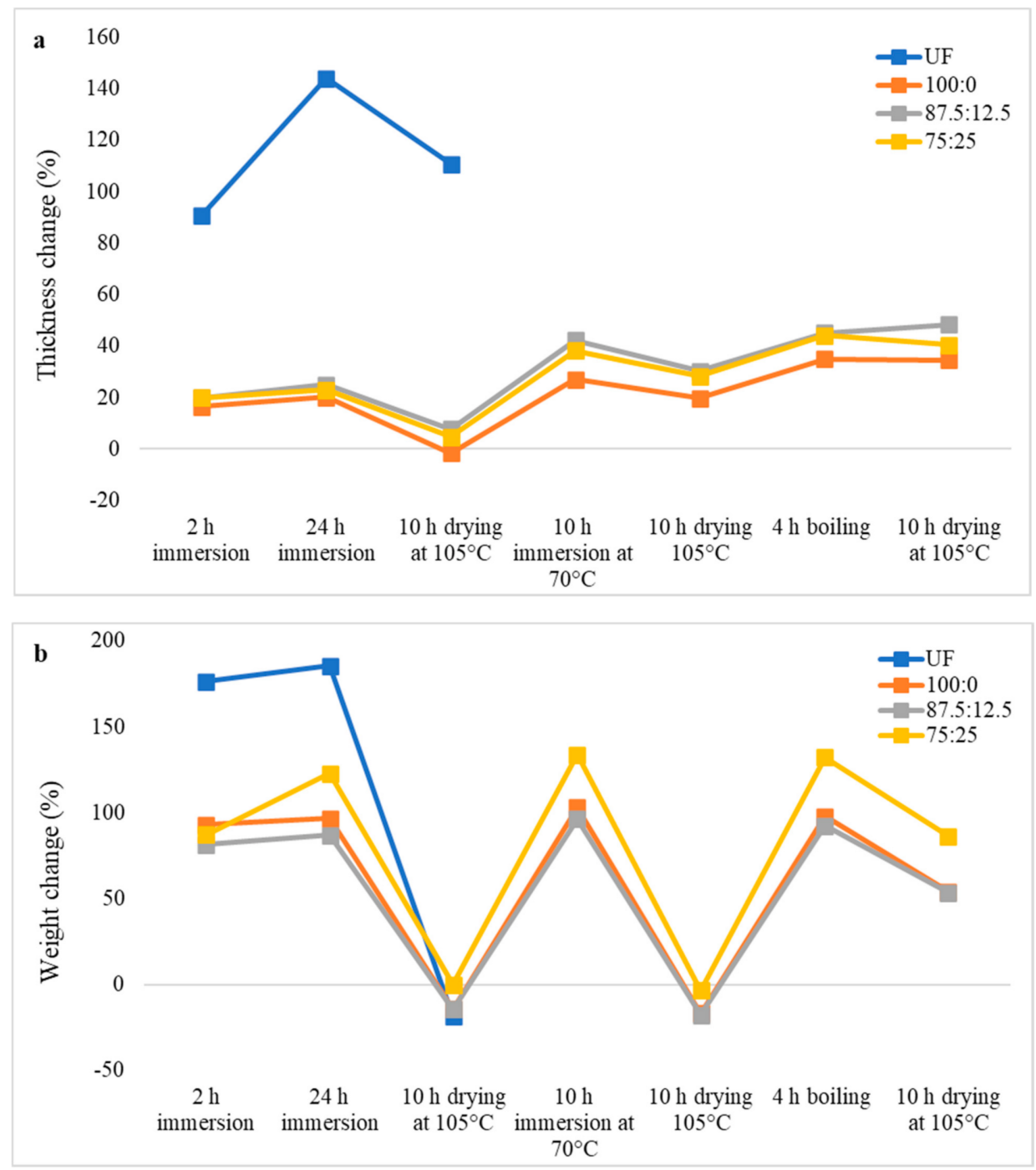

Figure 6. Thickness change (a) and weight change (b) of empty fruit bunch particleboard during cyclic-aging treatment.

For EFB particleboard, UF-bonded particleboard experienced disintegration after the first drying stage at $105{ }^{\circ} \mathrm{C}$, which was similar to UF-bonded OPF particleboard. The thickness change value of EFB particleboard bonded with pure citric acid was $35.08 \%$ after being boiled in hot water for $4 \mathrm{~h}$ (Figure 6a). Meanwhile, the weight values of EFB particleboard bonded with citric acid showed a very drastic change during each stage of the treatment (Figure 6b).

Generally, in most of the cases, the thickness and weight change values increased along with increasing starch content. OPT particleboard was the only exception, where the particleboard bonded with 87.5CA:12.5 starch displayed the lowest thickness change. It can be concluded that the addition of starch contributed to the increment of water-soluble compounds in the particleboards. As a result, the water resistance of the adhesive reduced as the particleboards were subjected to repeated immersion cycles. The water penetrated into the particleboard and weakened the bond of the particleboard [20]. Apart from that, the reduction in thermal stability after the addition of starch might also contribute to this observation. The particleboard was hot-pressed at $180^{\circ} \mathrm{C}$ in this study. Based on the TGA curves shown in Figure 3, at this temperature, pure citric acid experienced a weight loss of 5.9\%, while the mixture of citric acid and tapioca starch at 87.5:12.5 and 75:25 recorded weight losses of $9.0 \%$ and $15.8 \%$, respectively. Therefore, the citric acid compounds that 
contribute to the adhesiveness became lesser in the particleboard after the addition of starch, especially when $25 \%$ of starch was added.

With the exception of UF-bonded particleboard, all the particleboard bonded with citric acid and the mixture of citric acid and tapioca starch maintained their original shape after cyclic-aging treatment (Table 4). A darker color was observed for the citric-acidbonded particleboard after the cyclic-aging treatment. On the other hand, UF-bonded particleboard either displayed a huge extent of swelling or complete disintegration after the cyclic-aging treatment.

Table 4. Visual change of oil palm biomass particleboard before and after being subjected to cyclicaging treatment.

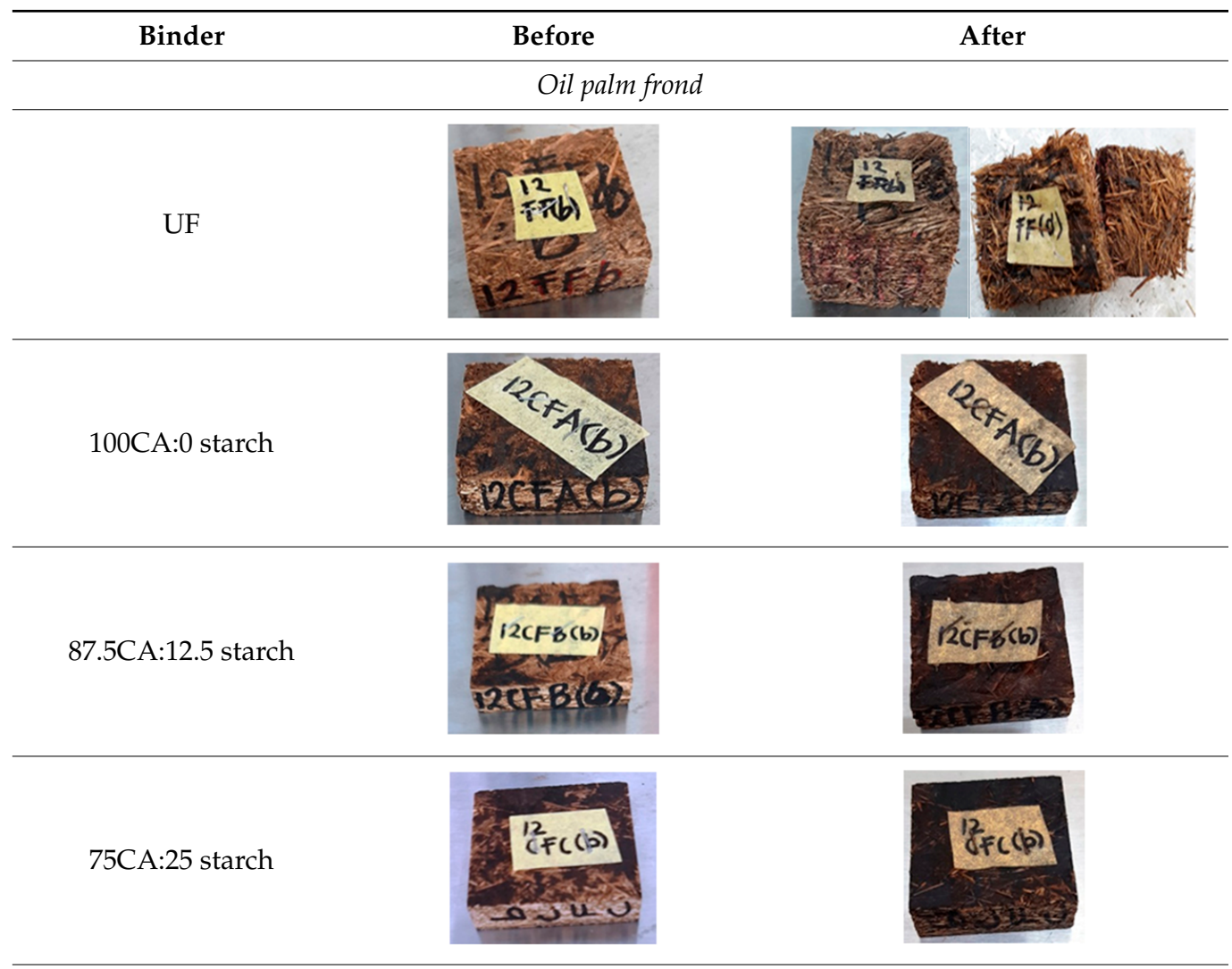

\section{Oil palm trunk}

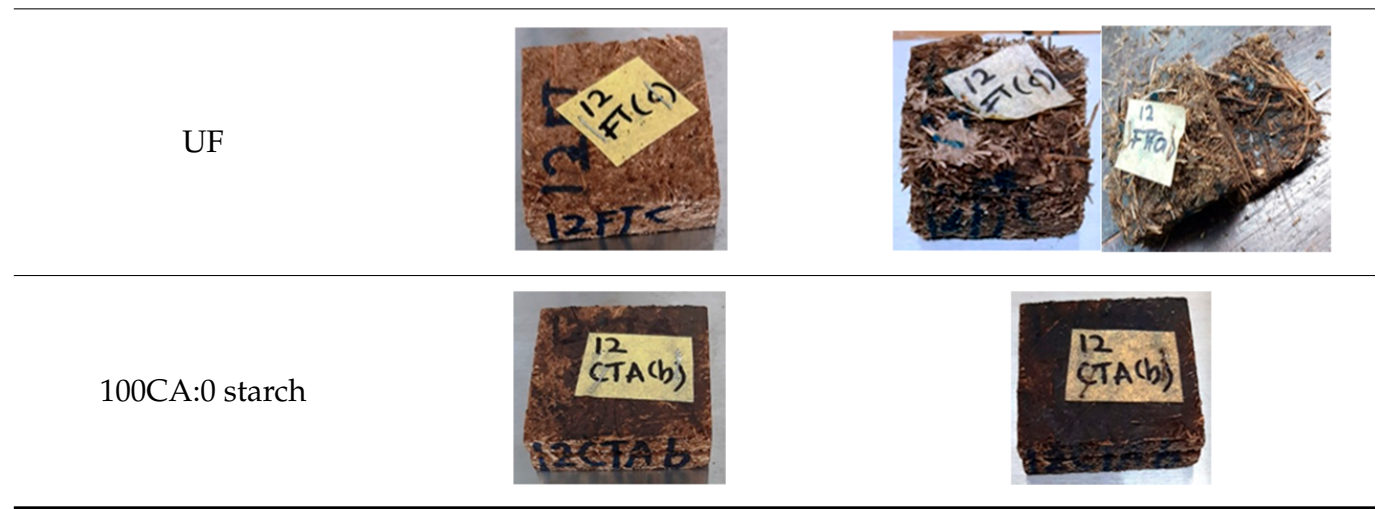


Table 4. Cont.

\begin{tabular}{|c|c|c|}
\hline Binder & Before & After \\
\hline 87.5CA:12.5 starch & & \\
\hline 75CA:25 starch & & \\
\hline
\end{tabular}

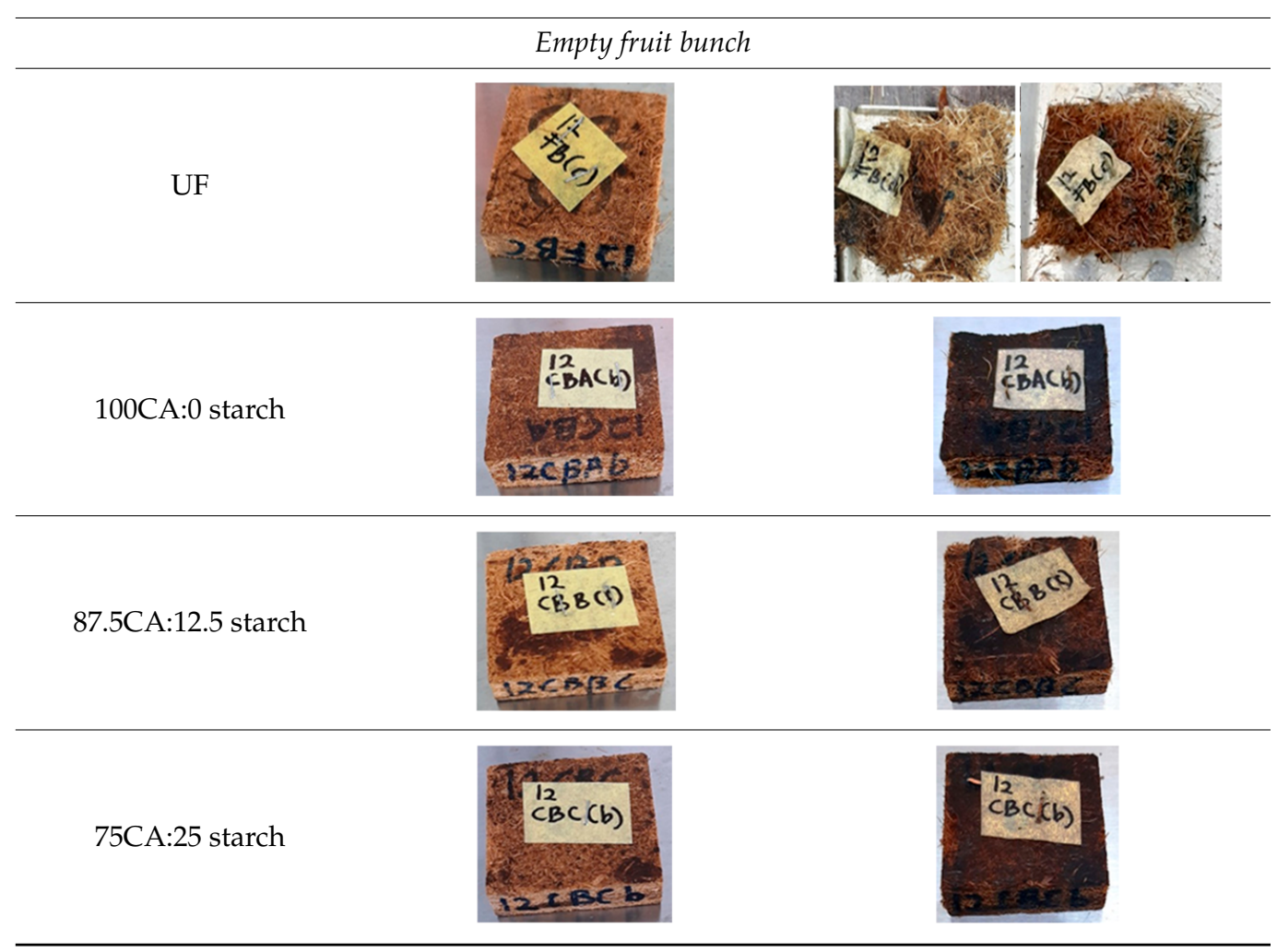

\section{Conclusions}

The effects of the addition of starch on the properties of oil palm biomass particleboard bonded with citric acid were investigated in this study. Generally, the addition of starch reduced the thermal stability of citric acid when subjected to lower temperatures. However, the mixture of citric acid and tapioca starch showed higher resistance at higher temperatures as indicated by the higher amount of residues compared to that of pure citric acid. In terms of the physical and mechanical properties of the particleboard produced, an addition of $12.5 \%$ starch might be beneficial. All of the citric-acid-bonded particleboard showed significantly better performance than that of UF-bonded particleboard. Some of the particleboard displayed better bending strength when bonded with a mixture of citric acid and tapioca starch at ratio of 87.5:12.5. Although some particleboards showed a decreasing trend after an addition of $12.5 \%$ starch, the decrement was, however, insignificant compared to those bonded with pure citric acid. The addition of $25 \%$ starch was unfavorable as it resulted in an adverse effect on the mechanical properties of the particleboard. On the other hand, a similar observation was obtained for physical properties of the particleboard. The addition of $12.5 \%$ starch slightly increased the TS and WA of the particleboard (although some showed a slight decrement) due to the solubility character- 
istic of starch in water. The increment was, however, acceptable. When subjected to the cyclic-aging treatment, citric-acid-bonded particleboard displayed superior dimensional stability as they maintained their original shape after the treatment. On the contrary, all the UF-bonded particleboard disintegrated half way through the treatment. Among oil palm biomasses, OPT and OPF exhibited better performance than that of EFB in terms of mechanical strength and dimensional stability. In conclusion, citric acid is a promising binder for particleboard as well as other wood composites. The addition of $12.5 \%$ starch could be beneficial to the mechanical properties, but addition beyond that loading is not recommended.

Author Contributions: Conceptualization, S.H.L. and P.B.; methodology, S.H.L.; software, W.C.L.; validation, S.H.L., W.C.L. and S.S.O.A.-E.; formal analysis, S.H.L.; investigation, R.Z.; resources, P.B.; data curation, R.Z.; writing-original draft preparation, R.Z. and S.H.L.; writing-review and editing, S.H.L., W.C.L., S.S.O.A.-E. and Z.I.; visualization, S.S.; supervision, P.B. and S.S.; project administration, P.B.; funding acquisition, P.B. and S.H.L. All authors have read and agreed to the published version of the manuscript.

Funding: This research was funded by the Fundamental Research Grant Scheme (FRGS 2019-1), Reference code: FRGS/1/2019/WAB07/UPM/02/3 by the Ministry of Higher Education, Malaysia and the Higher Institution Center of Excellence (HICoE).

Institutional Review Board Statement: Not applicable.

Informed Consent Statement: Not applicable.

Data Availability Statement: Not applicable.

Acknowledgments: The authors would like to acknowledge the Library of Universiti Putra Malaysia for providing access to the literature.

Conflicts of Interest: The authors declare no conflict of interest.

\section{References}

1. Malaysian Palm Oil Board (MPOB). Oil Palm Planted Area 2020. Available online: https://bepi.mpob.gov.my/index.php/en/ area/area-2020/oil-palm-planted-area-as-at-dec-2020 (accessed on 18 August 2021).

2. Mohammad Padzil, F.N.M.; Lee, S.H.; Ainun, Z.M.A.; Lee, C.H.; Abdullah, L.C. Potential of oil palm empty fruit bunch resources in nanocellulose hydrogel production for versatile applications: A review. Materials 2020, 13, 1245. [CrossRef] [PubMed]

3. Khalil, H.S.A.; Alwani, M.S.; Omar, A.K.M. Chemical composition, anatomy, lignin distribution, and cell wall structure of Malaysian plant waste fibers. BioResources 2006, 1, 220-232. [CrossRef]

4. Griffin, W.; Michalek, J.; Matthews, H.; Hassan, M. Availability of biomass residues for co-firing in Peninsular Malaysia: Implications for cost and GHG emissions in the electricity sector. Energies 2014, 7, 804-823. [CrossRef]

5. Lathrop, E.C.; Naffziger, T.R. Evaluation of fibrous agricultural residue for structural building board products-III. A process for the manufacture of high-grade products from wheat straw. Tappi 1994, 32, 319-330.

6. Penniston, K.L.; Nakada, S.Y.; Holmes, R.P.; Assimos, D.G. Quantitative assessment of citric acid in lemon juice, lime juice, and commercially-available fruit juice products. J. Endourol. 2008, 22, 567-570. [CrossRef] [PubMed]

7. Umemura, K.; Ueda, T.; Munawar, S.S.; Kawai, S. Application of citric acid as natural adhesive for wood. J. Appl. Polym. Sci. 2012, 123, 1991-1996. [CrossRef]

8. Lee, S.H.; Tahir, P.M.; Lum, W.C.; Tan, L.P.; Bawon, P.; Park, B.D.; Al Edrus, S.S.O.; Abdullah, U.H. A review on citric acid as green modifying agent and binder for wood. Polymers 2020, 12, 1692. [CrossRef] [PubMed]

9. Umemura, K.; Sugihara, O.; Kawai, S. Investigation of a new natural adhesive composed of citric acid and sucrose for particleboard. J. Wood Sci. 2013, 59, 203-208. [CrossRef]

10. Widyorini, R.; Nugraha, P.; Rahman, M.; Prayitno, T. Bonding ability of a new adhesive composed of citric acid-sucrose for particleboard. BioResources 2016, 11, 4526-4535. [CrossRef]

11. Widyorini, R.; Umemura, K.; Kusumaningtyas, A.R.; Prayitno, T.A. Effect of starch addition on properties of citric acid-bonded particleboard made from bamboo. BioResources 2017, 12, 8068-8077.

12. Widyorini, R.; Umemura, K.; Isnan, R.; Putra, D.R.; Awaludin, A.; Prayitno, T.A. Manufacture and properties of citric acid-bonded particleboard made from bamboo materials. Eur. J. Wood Wood Prod. 2016, 74, 57-65. [CrossRef]

13. Kusumah, S.S.; Umemura, K.; Guswenrivo, I.; Yoshimura, T.; Kanayama, K. Utilization of sweet sorghum bagasse and citric acid for manufacturing of particleboard II: Influences of pressing temperature and time on particleboard properties. J. Wood Sci. 2017, 63, 161-172. [CrossRef] 
14. Santoso, M.; Widyorini, R.; Prayitno, T.A.; Sulistyo, J. Bonding performance of maltodextrin and citric acid for particleboard made from nipa fronds. J. Korean Wood Sci. Technol. 2017, 45, 432-443.

15. Syamani, F.A.; Kusumah, S.S.; Astari, L.; Prasetiyo, K.W.; Wibowo, E.S.; Subyakto. Effect of pre-drying time and citric acid content on Imperata cylindrica particleboards properties. IOP Conf. Ser. Earth Environ. Sci. 2018, 209, 01203. [CrossRef]

16. Ferrandez-Garcia, M.T.; Ferrandez-Garcia, C.E.; Garcia-Ortuño, T.; Ferrandez-Garcia, A.; Ferrandez-Villena, M. Experimental evaluation of a new giant reed (Arundo Donax L.) composite using citric acid as a natural binder. Agronomy 2019, 9, 882. [CrossRef]

17. Liao, R.; Xu, J.; Umemura, K. Low density sugarcane bagasse particleboard bonded with citric acid and sucrose: Effect of board density and additive content. BioResources 2016, 11, 2174-2185. [CrossRef]

18. Zhou, H.X.; Hua, L.S.; Tahir, P.M.; Ashaari, Z.; Al-Edrus, S.S.O.; Ibrahim, N.A.; Abdullah, L.C.; Mohamad, S.F. Physico-Mechanical and Biological Durability of Citric Acid-Bonded Rubberwood Particleboard. Polymers 2021, 13, 98.

19. Lee, S.H.; Lum, W.C.; Zaidon, A.; Maminski, M. Microstructural, mechanical and physical properties of post heat-treated melamine-fortified urea formaldehyde-bonded particleboard. Eur. J. Wood Wood Prod. 2015, 73, 607-616. [CrossRef]

20. JIS A 5908. Particleboards. Japanese Industrial Standards (JIS); Japanese Standards Association: Tokyo, Japan, 2003.

21. TAPPI Standard T222 os-74. Acid-Insoluble Lignin in Wood and Pulp; Technical Association of the Pulp and Paper Industry (TAPPI): Atlanta, Georgia, 1974.

22. TAPPI Standard T203 os-74. Alpha-, Beta-, Gamma-Cellulose in Pulp; Technical Association of the Pulp and Paper Industry (TAPPI): Atlanta, Georgia, 1974.

23. Wise, L.E.; Murphy, M.; D'Addieco, A.A. Chlorite holocellulose, its fractionation and bearing on summative wood analysis and on studies on the hemicelluloses. Paper Trade J 1946, 122, 35-43.

24. Lee, S.H.; Ashaari, Z.; Chen, L.W.; San, H.P.; Peng, T.L.; Chow, M.J.; Chai, E.W.; Chin, K.L. Properties of particleboard with oil palm trunk as core layer in comparison to three-layer rubberwood particleboard. J. Oil Palm Res. 2015, $27,67-74$.

25. Kusumah, S.S.; Umemura, K.; Yoshioka, K.; Miyafuji, H.; Kanayama, K. Utilization of sweet sorghum bagasse and citric acid for manufacturing of particleboard I: Effects of pre-drying treatment and citric acid content on the board properties. Ind. Crop. Prod. 2016, 84, 34-42. [CrossRef]

26. Abdul Khalil, H.P.S.; Jawaid, M.; Hassan, A.; Paridah, M.T.; Zaidon, A. Oil palm biomass fibres and recent advancement in oil palm biomass fibres based hybrid biocomposites. In Composites and Their Applications, 1st ed.; Hu, N., Ed.; InTechOpen: London, $\mathrm{UK}, 2012$.

27. John, M.J.; Francis, B.; Varughese, K.T.; Thomas, S. Effect of chemical modification on properties of hybrid fiber biocomposites. Compos.-A Appl. Sci. Manuf. 2008, 39, 352-363. [CrossRef]

28. Grigoriu, A.; Passialis, C.; Voulgaridis, E. Experimental particleboards from kenaf plantations grown in Greece. Holz. Roh. Werkst. 2000, 58, 309-314. [CrossRef]

29. Papadopoulos, A.N.; Hill, C.A.S.; Gkaraveli, A.; Ntalos, G.A.; Karastergiou, S.P. Bamboo chips (Bambusa vulgaris) as an alternative lignocellulosic raw material for particleboard manufacture. Holz. Roh. Werkst. 2004, 62, 36-39. [CrossRef]

30. Silva, N.T.; Nascimento, N.F.; Cividanes, L.S.; Bertran, C.A.; Thim, G.P. Kinetics of cordierite crystallization from diphasic gels. J. Solgel. Sci. Technol. 2008, 47, 140-147. [CrossRef]

31. Chen, W.C.; Judah, S.N.M.S.M.; Ghazali, S.K.; Munthoub, D.I.; Alias, H.; Mohamad, Z.; Abd Majid, R. The Effects of Citric Acid on Thermal and Mechanical Properties of Crosslinked Starch Film. Chem. Eng. Trans. 2021, 83, 199-204.

32. Ali, I.; Ahmad, M.; Ganat, T. Development of a new formulation for enhancing the rheological and filtration characteristics of low-solids WBMs. J. Pet. Sci. Eng. 2021, 205, 108921. [CrossRef]

33. Hashim, R.; Nadhari, W.N.A.W.; Sulaiman, O.; Kawamura, F.; Hiziroglu, S.; Sato, M.; Sugimoto, T.; Seng, T.G.; Tanaka, R. Characterization of raw materials and manufactured binderless particleboard from oil palm biomass. Mater. Des. 2011, 32, 246-254. [CrossRef]

34. Boruszewski, P.; Borysiuk, P.; Mamiński, M.; Czechowska, J. Mat compression measurements during low-density particleboard manufacturing. BioResources 2016, 11, 6909-6919. [CrossRef]

35. Norul Izani, M.A.; Paridah, M.T.; Astimar, A.A.; Mohd, N.; Anwar, U.M.K. Mechanical and dimensional stability properties of medium-density fibreboard produced from treated oil palm empty fruit bunch. J. Appl. Sci. 2012, 12, 561-567. [CrossRef]

36. Ghani, A.; Bawon, P.; Ashaari, Z.; Wahab, M.W.; Hua, L.S.; Chen, L.W. Addition of propylamine as formaldehyde scavenger for urea formaldehyde-bonded particleboard. Wood Res. 2017, 62, 329-334.

37. Hashim, R.; Wan Nadhari, W.N.A.; Sulaiman, O.; Sato, M.; Hiziroglu, S.; Kawamura, F.; Sugimoto, T.; Seng, T.G.; Tanaka, R. Properties of binderless particleboard panels manufactured from oil palm biomass. BioResources 2012, 7, $1352-1365$.

38. Osman, N.F.; Bawon, P.; Lee, S.H.; Zaki, P.H.; Al-Edrus, S.S.O.; Halip, J.A.; Atkhar, M.S.M. Characterization of Particleboard Made from Oil Heat-Treated Rubberwood Particles at Different Mixing Ratios. BioResources 2020, 15, 6795-6810. [CrossRef] 